\title{
Isolation of Acetylcholinesterase from Apoptotic Human Lung Fibroblast Cells by Antibody Affinity Chromatography
}

\author{
Qi-Huang Jin ${ }^{1}$, Yu-Fang Shi ${ }^{2}$, Heng-Yi He ${ }^{1}$, Kelvin K.W. Ng ${ }^{1}$, Hua Jiang ${ }^{1}$, Lei Yang ${ }^{1}$, Zi-Qing Jiang ${ }^{1}$, and \\ Xue-Jun Zhang ${ }^{1}$ \\ ${ }^{1}$ Chinese Academy of Sciences, Shanghai, China, and 2 University of Medicine and Dentistry of New Jersey-Robert \\ Wood Johnson Medical School, Piscataway, NJ, USA
}

BioTechniques 33:S92-S97 (October 2002)

\begin{abstract}
Acetylcholinesterase (AChE; EC3.1.1.7) is well known for its role in the hydrolysis of acetylcholine at cholinergic synapses to terminate neurotransmission. In addition to its synaptic presence, AChE has been found to be in non-cholinergic cells such as hematopoietic and osteogenic cells. We have recently reported that $A C h E$ is expressed in various cells undergoing apoptosis. To characterize AChE in apoptotic cells and to investigate the role of $A C h E$ expression in apoptosis, we devised a method to purify AChE expressed in apoptotic human lung fibroblast cell line HLF. The isolation of this enzyme is mainly based on inhibitor ligand affinity chromatography using immobilized tacrine. However, this method is only effective in isolating active $A C h E$. Here we employed antibody-based chromatography and found that both active and inactive AChE were present in apoptotic HLF cells. Active AChE was predominantly observed in the nuclei of apoptotic cells, while inactive AChE was mainly present in the cytoplasm. Therefore, our method provides an opportunity to investigate further the role of AChE, especially inactive AChE, in apoptosis.
\end{abstract}

\section{INTRODUCTION}

Acetylcholinesterase (AChE; EC3.1.1.7) is responsible for the hydrolysis of acetylcholine at cholinergic synapses in the central and peripheral nervous systems. The enzyme exists in multiple molecular forms distinguished by their subunit associations. There are several AChE catalytic subunits, including a Ttype, an H-type, and an R-type, that differ at their C-terminals because of alternative splicing of a single gene in vertebrates $(20,21,23,24)$. AChE can be divided into homomeric and heteromeric forms, derived from catalytic subunits associated with either a lipid-linked subunit (14) or a collagen-like subunit (5). Homomeric forms include a globular G1 monomer and G2 dimer as well as a glycophospholipid-linked dimer. Heteromers consist of the asymmetric forms A4, A8, or A12, which is associated with a collagen-like subunit, and amphiphilic tetramers G4-linked to a 20-kDa hydrophobic anchor.

One interesting feature of AChE is that its expression is not restricted to cholinergic tissues. The enzyme is expressed in noncholinergic cells such as specific neuronal populations $(2,12,17)$, hematopoietic $(25,26,34)$, and osteogenic cells (11). In these cells, AChE possesses functions distinct from its well-known catalytic activity $(18,32)$. Recent studies suggest that AChE may function in regulating apoptosis. AChE expression is increased in apoptotic cells due to butyrylcholinesterase (BChE) suppression in retinospheroids using BChE antisense transfection (27). AChE may also participate directly in the regulation of bone marrow cell development by reducing the proliferative and expansive capacity of pluripotent stem cells by promoting apoptosis in their progenies $(19,31)$. Deletion of the AChE gene is associated with both myelodysplasia syndromes and acute myeloid leukemia, suggesting that AChE may in fact act as a tumor suppressor gene (10,33). AChE is expressed in a number of cell lines upon induction of apoptosis by various stimuli (38). When SK$\mathrm{N}-\mathrm{SH}$ cells, which normally express AChE, were induced to undergo apoptosis by long-term culture, the expression of AChE increased (37). These data indicate that AChE may function in apoptosis, although detailed mechanisms have yet to be defined.

One critical step in defining the function of $\mathrm{AChE}$ is to obtain AChE from various resources. Although AChE could be readily purified by inhibitor ligand affinity chromatography using immobilized N-methylacridinium (9), edrophonium (13), and tacrine (4), inactive AChE binds poorly to these inhibitor ligands (7). To isolate, characterize, and quantify total AChE from apoptotic cells, we developed an affinity chromatography with specific antibodies and were able to purify both active and inactive AChE.

\section{MATERIALS AND METHODS}

Inducing Apoptosis by Long-Term Culture and Detecting AChE Activity

HLF cells were grown as a monolayer in RPMI 1640 (Invitrogen, Carlsbad, CA, USA) supplemented with 10\% FCS and 4 $\mathrm{mM}$ glutamine. Cells were grown at $37^{\circ} \mathrm{C}$ in a humidified atmosphere containing $5 \% \mathrm{CO}_{2}$. To induce apoptosis, HLF cells were maintained in culture without changing the medium for 3-4 days (35). AChE activity was detected by the direct staining with thiocholine (15). The nuclei were stained with $10 \mu \mathrm{M}$ fluorochrome Hoechst 33258 for $10 \mathrm{~min}$ at $37^{\circ} \mathrm{C}$. 


\section{AChE Cytochemical Staining and TUNEL}

AChE activity was detected according to the method of Karnovsky and Roots (15). HLF cells were centrifuged onto slides by Cytospin, subjected to a permeabilization solution $\left(0.1 \%\right.$ Triton $^{\circledR} \mathrm{X}-100,0.1 \%$ sodium citrate) for $2 \mathrm{~min}$ on ice, and then incubated with $50 \mathrm{~mL}$ TUNEL reaction mixture (Roche Applied Science, Indianapolis, IN, USA) for $60 \mathrm{~min}$ at $37^{\circ} \mathrm{C}$ in the dark. The labeled cells were then washed, transferred onto glass slides, and observed under a fluorescence microscope.

\section{AChE Immunofluorescence Staining and TUNEL}

HLF cells were centrifuged onto slides, fixed in 3\% paraformaldehyde for $40 \mathrm{~min}$ at $4^{\circ} \mathrm{C}$, and then treated with the permeabilization solution for 4 min. After blocking in 3\% BSA for 1 $\mathrm{h}$ at room temperature, the slides were incubated with primary AChE-antibody (BD Biosciences, San Jose, CA, USA) at 1:100 dilution for $2 \mathrm{~h}$ and then incubated with the secondary mouse IgG antibody (Santa Cruz Biotechnology, Santa Cruz, CA, USA) at $1: 100$ dilution for $1 \mathrm{~h}$ at $37^{\circ} \mathrm{C}$. After washing three times with PBS, apoptosis was detected using TUNEL as described above.

\section{Preparation of Polyclonal Anti-AChE Antibody}

To obtain a large amount of anti-AChE antibody for affinity chromatography, three rabbits were immunized with Electrophorus electricus (eel) AChE (Sigma, St. Louis, MO, USA). Four inoculations at 20-day intervals were made: the first injection using complete Freund's adjuvant and three additional inoculations with incomplete Freund's adjuvant. Approximately $1 \mathrm{mg}$ eel AChE was used for each injection. Crude IgG fractions were prepared by ammonium sulfate precipitation. IgG fractions were diluted with $5 \mathrm{~mL}$ PBS and dialyzed against PBS to remove ammonia ions. The antibody was then quantitated and lyophilized.

\section{Preparation of Antibody Affinity Column}

The purified antibody was coupled to $\mathrm{CNBr}$-Sepharose ${ }^{\circledR}$ (Amersham Biosciences, Piscataway, NJ, USA) at a ratio of approximately $10 \mathrm{mg}$ protein/ $\mathrm{mL}$ final bed volume, according to the manufacturer's instructions. In brief, the $\mathrm{CNBr}$-Sepharose was hydrated in $1 \mathrm{mM} \mathrm{HCl}, \mathrm{pH} 3.0$, and washed three times by sand filtration with $1 \mathrm{mM} \mathrm{HCl}$. The $\mathrm{CNBr}$-Sepharose was then mixed with the antibody at $10 \mathrm{mg} / \mathrm{mL}$ in $0.1 \mathrm{M}$ carborate, 0.5 $\mathrm{M} \mathrm{NaCl}, \mathrm{pH}$ 8.3. The reaction was carried out overnight at $4^{\circ} \mathrm{C}$ with constant rotation. Uncoupled sites were blocked with 0.1 $\mathrm{M}$ ethandamine for $2 \mathrm{~h}$ at ambient temperature and subjected to three wash cycles alternating between $0.1 \mathrm{M}$ acetate buffer, $0.5 \mathrm{M} \mathrm{NaCl}, \mathrm{pH} 4.0$, and $0.1 \mathrm{M}$ Tris- $\mathrm{HCl}$ buffer, $0.5 \mathrm{M} \mathrm{NaCl}$, $\mathrm{pH}$ 8.0. The column was packed and equilibrated in $0.05 \mathrm{M}$ Tris, $0.15 \mathrm{M} \mathrm{NaCl}$, and $0.02 \% \mathrm{NaN}_{3}, \mathrm{pH} 8.0$.

\section{AChE Purification from Apoptotic HLF Cells}

Unless stated otherwise, all steps of purification were performed at $4^{\circ} \mathrm{C}$.

Preparation of cell lysate. The apoptotic cells were collected and washed with PBS, $\mathrm{pH}$ 7.0. A buffer $(50 \mathrm{mM}$ Tris- $\mathrm{HCl}, 150$
$\mathrm{mM} \mathrm{NaCl}, 1 \mu \mathrm{g} / \mathrm{mL}$ Aprotinin, $1 \%$ Triton X-100, $\mathrm{pH} 8.0$ ) was added to cell pellets while vortex mixing. The cell lysate was incubated on ice for $30 \mathrm{~min}$ and then treated with supersonic wave for $2 \mathrm{~min}$. Afterwards, the lysate was centrifuged at 1700x $g$ for $4 \mathrm{~min}$ at $4^{\circ} \mathrm{C}$. The supernatant was dialyzed against PBS, $\mathrm{pH} 7.0$, and concentrated to $13 \mathrm{mg} / \mathrm{mL}$ by lyophilization.

Protein binding to antibody affinity gel. Approximately 20 $\mathrm{mL}$ cell lysate (230 $\mathrm{mg}$ protein) was mixed with an antibody affinity gel, which had been equilibrated with $0.05 \mathrm{M} \mathrm{PBS,} \mathrm{pH}$ 7.5 , and interacted for $20 \mathrm{~h}$ at $4^{\circ} \mathrm{C}$ with constant rotation. To remove unbound proteins, the gel was washed by sand filtration with PBS, pH 7.5, and loaded to the column. The column was continually washed until no protein was detected in the filtrate.

AChE elution. The bound AChE was eluted with $0.1 \mathrm{M}$ Glysine- $\mathrm{HCl}, \mathrm{pH}$ 2.5. All elute was pooled, concentrated by lyophilization, and dialyzed to remove saline. The purified $\mathrm{AChE}$ was quantitated and stored in aliquots at $-70^{\circ} \mathrm{C}$.

\section{SDS-PAGE and Western Blotting}

SDS-PAGE was performed according to the method of Laemmli et al. (16). Proteins were stained with Coomassie ${ }^{\circledR}$ Brilliant Blue. After electrophoresis, the proteins were transferred onto nitrocellulose membrane elctrophoretically. High 
molecular weight markers (Pierce Chemical, Rockford, IL, USA) were included for molecular weight calibration. A constant electric current of $0.065 \mathrm{~mA} / \mathrm{cm}^{2}$ film was applied for $2 \mathrm{~h}$. Immediately after transfer, the membrane was soaked for $1 \mathrm{~h}$ at $37^{\circ} \mathrm{C}$ in TBST $(10 \mathrm{mM}$ Tris- $\mathrm{HCl}, 150 \mathrm{mM} \mathrm{NaCl}, 0.1 \%$ Tween ${ }^{\circledR} 20, \mathrm{pH} 7.2$ ) containing $5 \%$ fat-free dried milk. Thereafter, the blot was incubated for $1 \mathrm{~h}$ at room temperature with AChE monoclonal antibody diluted to $1 / 2500$ in TBST containing 5\% fat-free dried milk. After three washings with TBST for $10 \mathrm{~min}$ each, the blot membrane was incubated with HRPconjugated anti-mouse IgG diluted to $1 / 2000$ for $1 \mathrm{~h}$ and then washed three times, each for $10 \mathrm{~min}$, with TBST. HRP activity was detected using ECL ${ }^{\circledR}$ (Santa Cruz Biotechnology).

\section{Determining AChE Activity}

AChE activity was determined spectrophotometrically in a 96-well microplate using a modified Ellman's assay as described (10a). The assay was performed in the presence of $0.5 \mathrm{mM}$ acetylthiocholine, $50 \mathrm{mM}$ sodium phosphate buffer $(\mathrm{pH} \mathrm{8.0)}$ ),

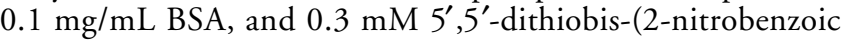
acid) at $27^{\circ} \mathrm{C}$. The sample's absorbance value at $405 \mathrm{~nm}$ was analyzed using a spectrophotometer (model EL311; Bio-Tek, Winooski, VT, USA).

\section{RESULTS AND DISCUSSION}

\section{Induction of Apoptosis and Detection of AChE Activity}

HLF is a fibroblast cell line derived from human lung that attaches to plastic culture ware in vitro. Although HLF does not require specific growth factors, prolonged culture in vitro could lead to apoptosis. In such aged cultures, apoptotic HLF cells detach from plastic and can be harvested from suspension. In the

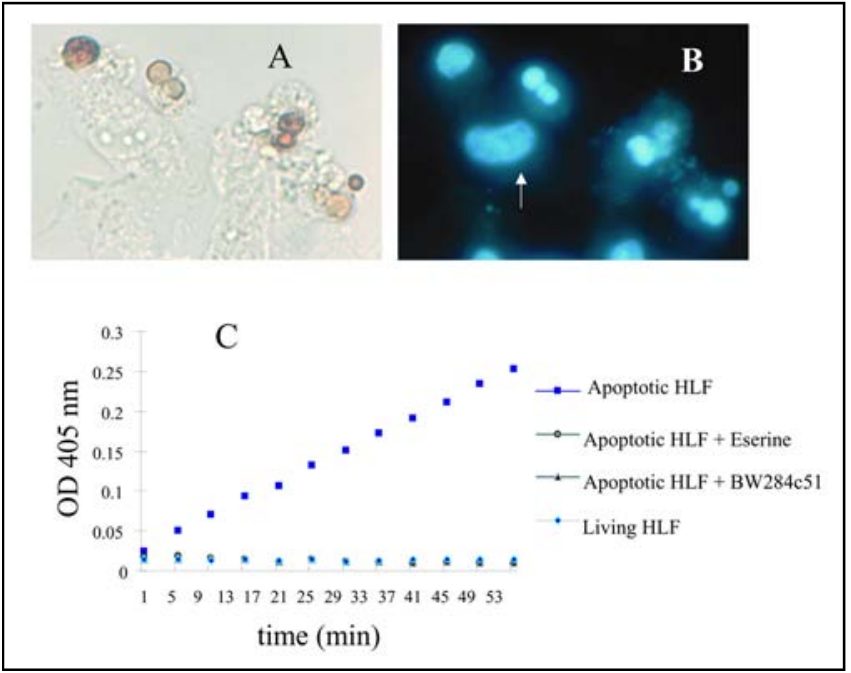

Figure 1. Existence of AChE in apoptotic cells. HLF cells in a aged culture were stained by (A) AChE cytochemical staining and (B) Hoechst 33258. The arrows indicate negative AChE staining in cells with a normal nucleus. (C) AChE activity was determined spectrophotometrically in a 96-well microplate using a modified Ellman's assay. suspended cells, we have found that AChE activity appeared in the nuclei of the majority of apoptotic cells and in the cytoplasm of some apoptotic cells upon cytochemical staining with thiocholine (Figure 1A). The cells were also stained with fluorochrome Hoechst 33258 to show chromatin condensation and apoptotic bodies (Figure 1B). AChE activity was not present in living HLF cells, as compared to the strong AChE activity found in the apoptotic cells, which could be inhibited by AChE-specific inhibitors BW284c51 and eserine (Figure 1C). In addition to prolonged culture, apoptosis in HLF cells was also induced by treatment with G418, ceramide, or UV-B. Upon receiving these treatments, HLF cells also undergo apoptosis and reveal AChE activity in a similar fashion as that of prolonged culture (data not shown). Because of its simplicity, we have elected prolonged culture as a primary method to induce apoptosis.

\section{Presence of Active and Inactive AChE in Apoptotic HLF Cells}

To determine the consistency of the presence of AChE protein and its activity, we detected the enzymatic activity of AChE and total AChE protein with antibodies. Karnovsky and Roots (15) devised a classical method to detect the AChE activity with thiocholine. With this protocol, only active AChE was detected by thiocholine. The presence of active and inactive AChE was also detected by immunofluorescence with AChE-specific polyclonal antibodies. We found that active AChE was mainly detected in the nuclei and apoptotic bodies as indicated by the TUNEL assay. Immunocytochemistry showed that AChE existed in the either nuclei or cytoplasm of apoptotic cells (Figure 2). However, neither AChE protein nor its activity was found in TUNEL-negative HLF cells. (Figure 3).

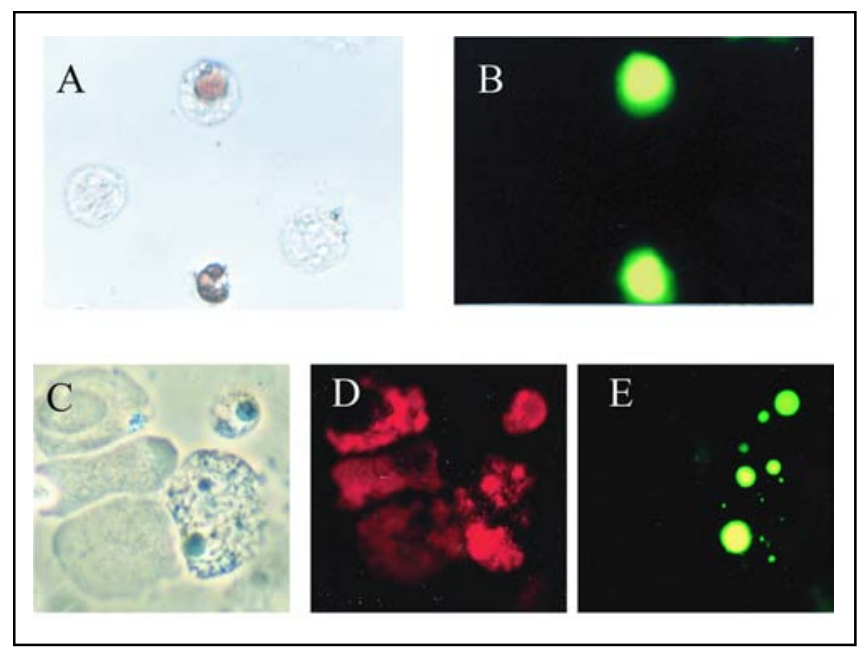

Figure 2. Active and inactive AChE is present in apoptotic cells. Both attached and detached apoptotic HLF cells were collected and stained for AChE by cytochemical staining or immunofluorescence to show co-localization of AChE and DNA fragmentation by TUNEL assay in apoptotic cells. (A) Brown stains indicate AChE-positive cells with cytochemical staining. (B) TUNEL-positive cells indicated genomic DNA fragmentation. (C) The cells were observed under a light field microscope. (D) Immunofluorescence indicated that AChE existed in both the nuclei and cytoplasm of apoptotic cells. Some non-apoptotic cells were also positive, which indicated that $\mathrm{AChE}$ was expressed at the early stages of apoptosis. (E) A TUNEL assay showed the presence of apoptotic cells. 


\section{Purification of AChE}

We have generated a rabbit anti-eel AChE polyclonal antibody that reacts with human AChE expressed by apoptotic HLF. We found that the isolated rabbit anti-eel AChE polyclonal antibody was able to recognize both eel and human AChE expressed by apoptotic HLF cells (Figure 4) on Western analysis. The main band at $80 \mathrm{kDa}$ in lane 1 represents eel $\mathrm{AChE}$, while the subsequent bands at 60,70 , and $30 \mathrm{kDa}$ indicate degraded AChE. Lane 2 contains the apoptotic HLF cell lysate at $68 \mathrm{kDa}$. The purified protein was again tested for its reactivity to AChEspecific antibodies by Western analysis. As shown in Figure 5, the purified protein strongly react to anti-AchE and is the same molecular weight as AchE in apoptotic cells.

The rabbit anti-eel AChE polyclonal antibody was coupled to Sepharose beads and was used for chromatography to isolate human AChE from apoptotic HLF cells. The concentration of purified AChE was determined by UV absorbance. Approximately $1 \mathrm{mg}$ AChE was isolated from $10^{9}$ apoptotic HLF cells. The purified AChE appears as a $68-\mathrm{kDa}$ band on Western analysis. Therefore, the inactive and active AChE forms have similar immunological reactivity and molecular weights, as others have previously reported $(6,8)$. It has been reported that purified AChE does not always possess enzymatic activity. The difficulty in detecting the activity of AChE may have been

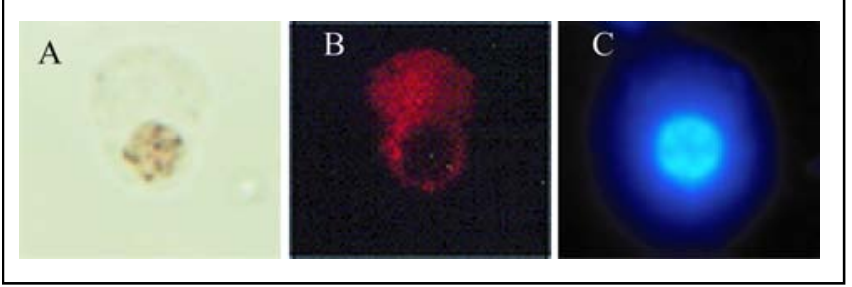

Figure 3. Both active and inactive AChE existed in the same apoptotic HLF cell. (A) AChE cytochemical staining exhibits active AChE, as detected by the method of Karnovsky and Roots (15). (B) Immunofluorescence shows that inactive AChE exists in cytoplasm. The negative appearance in the nucleus was due to the brown precipitate obstructing the UV absorbance and fluorescence emission. (C) Hoechst 33258 was used to stain the condensed nucleus.

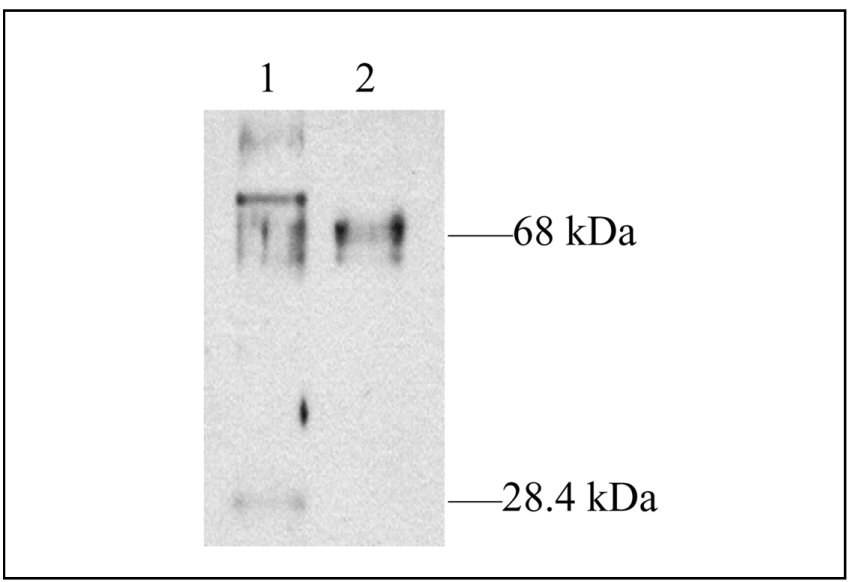

Figure 4. The purified protein is homogeneous. Western analysis indicates the specificity of the isolated antibody to eel AChE (lane 1) and apoptotic HLF lysate (lane 2). attributed to the following reasons. First, the steps taken in the purification process may have affected AChE activity. Second, a large portion of the isolated AChE may be of the inactive type.

Previous research has shown that inactive AChE existed in increased amounts in the cytoplasm. A stable pool of inactive AChE, $70 \%-80 \%$ of total enzyme, was found in chick brain and muscles (6). Choi et al. (8) found that calcitonin gene-related peptide increased the expression of AChE mRNA and inactive AChE protein in cultured chick myotubes. The proportion of inactive versus active AChE varied significantly during development in quail brain (1). These results indicate that inactive AChE may have a similar role to active AChE. Because inactive and active AChE were present in apoptotic cells at the same time and have similar immunological properties and molecular weights, it is highly possible that the active and inactive forms are inter-convertible. Invertebrate cholinesterases, catalytic subunits with different glycosylation patterns, have been isolated from different tissues $(3,22,28,36)$. In the brain of Alzeimer's disease patients, which correlates with abnormal AChE activity, the level and distribution of AChE isoforms are profoundly altered $(29,30)$. Inactive AChE may have different modifications from active $\mathrm{AChE}$ and therefore may have different functions. Another explanation may be that newly synthesized polypeptides fold into different conformations, and the probability of its orientation towards the active or inactive state is regulated by a nonclassical function. These uncertainties may be resolved by further research on the modifications, functions, and properties of inactive and active AChE in apoptotic cells.

\section{ACKNOWLEDGMENTS}

This work was supported by the National Natural Science Foundation of China (NSFC 3957035), grant no. G1999053905, and National Institutes of Health grant no. CA76492.

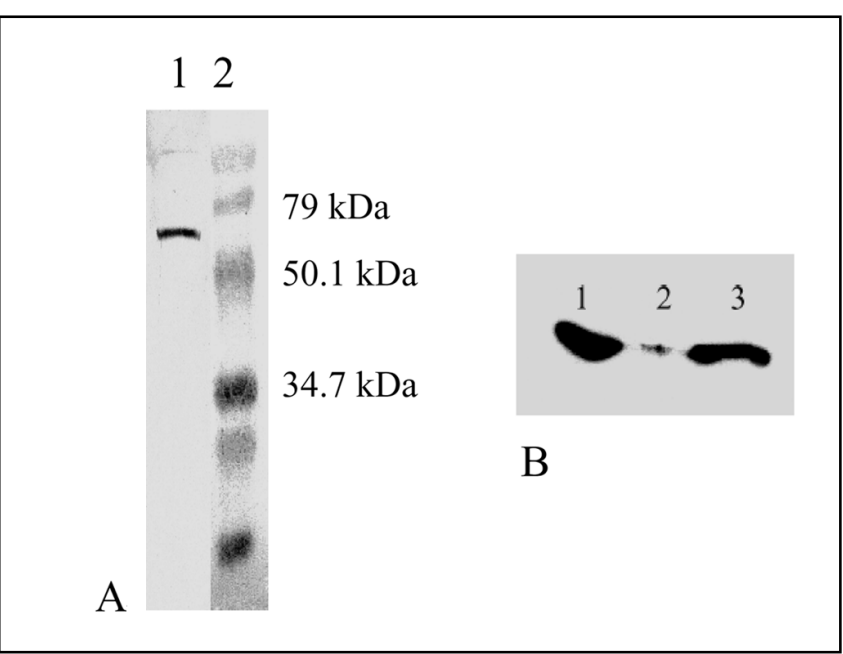

Figure 5. The purified protein reacts to antibodies to AChE. AChE purified from apoptotic cells was identified by (A) Coomassie Brilliant Blue staining. Only one band appeared between 50 and $79 \mathrm{kDa}$. (B) Western analysis with monoclonal antibody to $\mathrm{AChE}$ confirmed that the protein is $\mathrm{AChE}$. Lane 1, purified AChE; lane 2, live HLF cells; and lane 3, apoptotic cells. 


\section{REFERENCES}

1.Anselmet, A., M. Fauquet, J.M. Chatel, Y. Maulet, J. Massoulie, and F.M. Vallette. 1994. Evolution of acetylcholinesterase transcripts and molecular forms during development in the central nervous system of the quail. J. Neurochem. 62:2158-2165.

2.Bernard, V., C. Legay, J. Massoulie, and B. Bloch. 1995. Anatomical analysis of the neurons expressing the acetylcholinesterase gene in the rat brain, with special reference to the striatum. Neuroscience 64:995-1005.

3.Campoy, F.J., J. Cabezas-Herrera, and C.J. Vidal. 1992. Interaction of AChE with Lens culinaris agglutinin reveals differences in glycosylation of molecular forms in sarcoplasmic reticulum membrane subfractions. J. Neurosci. Res. 33:568-578.

4.Carroll, R.T., J.L. Grimm, T.W. Hepburn, and M.R. Emmerling. 1995. Purification of acetylcholinesterase by tacrine affinity chromatography. Prot. Expr. Purif. 6:389-393.

5.Cartaud, J., S. Bon, and J. Massoulie. 1978. Electrophorus acetycholinesterase. Biochemical and electron microscope characterization of low ionic strength aggregates. J. Cell Biol. 77:315-322.

6.Chatel, J.M., J. Eichler, F.M. Vallette, S. Bon, J. Massoulie, and J. Grassi. 1994. Two-site immunoradiometric assay of chicken acetylcholinesterase: active and inactive molecular forms in brain and muscle. J. Neurochem. 63:1111-1118.

7.Chatel, J.M., J. Grassi, Y. Frobert, J. Massoulie, and F.M. Vallette. 1993. Existence of an inactive pool of acetylcholinesterase in chicken brain. Proc. Natl. Acad. Sci. USA 90:2476-2480.

8.Choi, R.C., P.W. Leung, T.T. Dong, D.C. Wan, and K.W. Tsim. 1996. Calcitonin gene-related peptide increases the expression of acetylcholinesterase in cultured chick myotubes. Neurosci. Lett. 217:165-168.

9.Dudai, Y., I. Silman, M. Shinitzky, and S. Blumberg. 1972. Purification by affinity chromatography of the molecular forms of acetylcholinesterase present in fresh electric-organ tissue of electric eel. Proc. Natl. Acad. Sci. USA 69:2400-2403.

10.Ehrlich, G., E. Viegas-Pequignot, D. Ginzberg, L. Sindel, H. Soreq, and H. Zakut. 1992. Mapping the human acetylcholinesterase gene to chromosome $7 q 22$ by fluorescent in situ hybridization coupled with selective PCR amplification from a somatic hybrid cell panel and chromosome-sorted DNA libraries. Genomics 13:1192-1197.

10a.Ellman, G.L., K.D. Courtney, V. Andres, and R.M. Featherstone. 1961. A new rapid colorimetric determination of acetylcholinesterase activity. Biochem. Pharmacol.

11.Grisaru, D., E. Lev-Lehman, M. Shapira, E. Chaikin, J.B. Lessing, A. Eldor, F. Eckstein, and H. Soreq. 1999. Human osteogenesis involves differentiation-dependent increases in the morphogenically active $3^{\prime}$ alternative splicing variant of acetylcholinesterase. Mol. Cell Biol. 19:788-795.

12.Hammond, P., R. Rao, C. Koenigsberger, and S. Brimijoin. 1994. Regional variation in expression of acetylcholinesterase mRNA in adult rat brain analyzed by in situ hybridization. Proc. Natl. Acad. Sci. USA 91:10933-10937.

13. Hodgson, A.J. and I.W. Chubb. 1983. Isolation of the secretory form of soluble acetylcholinesterase by using affinity chromatography on edrophoniumSepharose. J. Neurochem. 41:654-662.

14.Inestrosa, N.C., W.L. Roberts, T.L. Marshall, and T.L. Rosenberry. 1987. Acetylcholinesterase from bovine caudate nucleus is attAChEd to membranes by a novel subunit distinct from those of acetylcholinesterases in other tissues. J. Biol. Chem. 262:4441-4444.

15.Karnovsky, M.J. and L. Roots. 1964. A direct coloring thiocholine method for cholinesterases. J. Histochem. Cytochem. 12:219-222.

16.Laemmli, U.K. 1970. Cleavage of structural proteins during the assembly of the head of bacteriophage T4. Nature 227:680-685.

17.Landwehrmeyer, B., A. Probst, J.M. Palacios, and G. Mengod. 1993. Expression of acetylcholinesterase messenger RNA in human brain: an in situ hybridization study. Neuroscience 57:615-634.

18.Layer, P.G. and E. Willbold. 1995. Novel functions of cholinesterases in development, physiology and disease. Prog. Histochem. Cytochem. 29:1-94.

19.Lev-Lehman, E., D. Ginzberg, G. Hornreich, G. Ehrlich, A. Meshorer, F. Eckstein, H. Soreq, and H. Zakut. 1994. Antisense inhibition of acetyl cholinesterase gene expression causes transient hematopoietic alterations in vivo. Gene Ther. 1:127-135.

20.Li, Y., S. Camp, T.L. Rachinsky, D. Getman, and P.J. Taylor. 1991. Gene structure of mammalian acetylcholinesterase. Alternative exons dictate tissuespecific expression. J. Biol. Chem. 266:23083-23090.

21.Li, Y., S. Camp, and P.J. Taylor. 1993. Tissue-specific expression and alter- native mRNA processing of the mammalian acetylcholinesterase gene. J. Biol. Chem. 268:5790-5797.

22.Lockridge, O, C.F. Bartels, T.A. Vaughan, C.K. Wong, S.E. Norton, and L.L. Johnson. 1987. Complete amino acid sequence of human serum cholinesterase. J. Biol. Chem. 262.549-557.

23. Massoulie, J. and S. Bon. 1982. The molecular forms of cholinesterase and acetylcholinesterase in vertebrates. Annu. Rev. Neurosci. 5:57-106.

24.Massoulie, J., L. Pezzementi, S. Bon, E. Krejci, and F.M. Vallette. 1993 Molecular and cellular biology of cholinesterases. Prog. Neurobiol. 41:31-91.

25.Ott, P., A. Lustig, U. Brodbeck, and J.P. Rosenbusch. 1982. Acetycholinesterase from human erythrocytes membranes: dimers as functional units. FEBS Lett. 138:187-189.

26.Paulus, J.M., J. Maigne, and E. Keyhani. 1981. Mouse megakaryocytes secrete acetylcholinesterase. Blood 58:1100-1106.

27. Robitzki, A., A. Mack, U. Hoppe, A. Chatonnet, and P.G. Layer. 1998. Butyrylcholinesterase antisense transfection increases apoptosis in differentiating retinal reaggregates of the chick embryo. J. Neurochem. 71:1413-1420.

28.Saez Valero, J., G. Sberna, C.A. McLean, C.L. Masters, and D.H. Small. 1997. Glycosylation of acetylcholinesterase as diagnostic marker for Alzheimer's disease. Lancet 350.929.

29.Shen, Z.X. 1998. CSF cholinesterase activity in demented and non-demented subjects. Neuroreport 9:483-488.

30.Small, D.H., S. Michaelson, and G. Sberna. 1996. Non-classical actions of cholinesterases: role in cellular differentiation, tumorigenesis and Alzheimer's disease. Neurochem. Int. 28:453-483.

31.Soreq, H., D. Patinkin, E. Lev-Lehman, M. Grifman, D. Ginzberg, F. Eckstein, and H. Zakut. 1994. Antisense oligonucleotide inhibition of acetylcholinesterase gene expression induces progenitor cell expansion and suppresses hematopoietic apoptosis ex vivo. Proc. Natl. Acad. Sci. USA 91:7907-7911.

32.Soreq, H. and S. Seidman. 2001. Acetylcholinesterase-new roles for an old actor. Nat. Rev. Neurosci. 2:294-302.

33.Stephenson, J., B. Czepulkowski, W. Hirst, and G.J. Mufti. 1996. Deletion of the acetylcholinesterase locus at 7q22 associated with myelodysplastic syndromes (MDS) and acute myeloid leukaemia (AML). Leuk. Res. 20:235241.

34.Szelenyi, J.G., E. Bartha, and S.R. Hollan. 1982. Acetylcholinesterase activity of lymphocytes: an enzyme characteristic of T-cells. Br. J. Haematol. 50:241-245

35.Torriglia, A., C. Negri, E. Chaudun, E. Prosperi, Y. Courtois, M.F. Counis, and A.I. Scovassi. 1999. Differential involvement of DNases in HeLa cell apoptosis induced by etoposide and long term-culture. Cell Death Differ. 6:234-244.

36.Treskatis, S., C. Ebert, and P.G. Layer. 1992. Butyrylcholinesterase from chicken brain is smaller than that from serum: its purification, glycosylation, and membrane association. J. Neurochem. 58:2236-2247.

37.Yang, L., H.Y. He, and X.J. Zhang. 2002. Increased expression of intranuclear AChE involved in apoptosis of SK-N-SH cells. Neurosci. Res. 42:261268.

38.Zhang, X.J., L. Yang, Q. Zhao, J.P. Caen, H.Y. He, Q.H. Jin, L.H. Guo, M. Alemany M, et al. 2002. Induction of acetylcholinesterase expression during apoptosis in various cell types. Cell Death Differ. 9.790-800.

\section{Address correspondence to:}

Dr. Xue-Jun Zhang

Laboratory of Molecular Cell Biology

Institute of Biochemistry and Cell Biology

Shanghai Institutes for Biological Sciences

Chinese Academy of Sciences

320 YueYang Road

Shanghai 200031, China

e-mail: zhang-xj@sunm.shcnc.ac.cn

or

Dr. Yu-Fang Shi

Department of Molecular Genetics and Microbiology

University of Medicine and Dentistry of New Jersey-Robert Wood Johnson

Medical School

661 Hoes Lane

Piscataway, NJ 08854, USA

e-mail: shiyu@umdnj.edu 